Borowska A., Przedsiębiorczość spoteczna warunkiem rozwoju lokalnej gospodarki, „Ekonomia i Prawo", Polszakiewicz B., Boehlke J. (red.), Tom XII, nr 1/2013, ss. 105-114 DOI: http:// dx.doi.org/10.12775/EiP.2013.009

\title{
PRZEDSIĘBIORCZOŚĆ SPOŁECZNA CZYNNIKIEM ROZWOJU LOKALNEJ GOSPODARKI
}

\author{
Przedsiębiorca spoteczny potrafi zmienić \\ zdolności sprawcze spoteczeństwa.
}

P. Drucker ${ }^{1}$

\section{STRESZCZENIE}

Przedsiębiorczość społeczna, element „nowej ekonomii społecznej”, działająca w ramach Trzeciego Sektora, jest w stanie wychwycić i w innowacyjny sposób rozwiązać te potrzeby społeczne, których nie są w stanie zaspokoić instytucje charytatywne i państwo, z uwagi na biurokratyczną postawę, opieranie się zmianom, brak elastyczności, aktywności i innowacyjności. Rozwój przedsiębiorczości lokalnej może być wspierany przez samorządy lokalne, świat nauki i media, ponieważ może ona przynieść wiele korzyści społeczno-ekonomicznych w skali jednostki, społeczeństwa i świata.

Słowa kluczowe: przedsiębiorczość społeczna, rozwój lokalny

Klasyfikacja JEL: O17, P13

* Alina Borowska, Politechnika Białostocka, Wydział Zarządzania, Katedra Ekonomii i Nauk Społecznych, ul. Ojca Tarasiuka 2, 16-001 Kleosin, e-mail: alabor@tlen.pl.

${ }^{1} \mathrm{Za}$ : D. Bornstein, Jak zmieniać swwiat. Przedsiębiorcy spoteczni - wizjonerzy naszych czasów, Wyd. AnWero, Gdańsk 2008, s. 24. 


\title{
SOCIAL ENTREPRENEURSHIP CONDITION FOR THE DEVELOPMENT OF THE LOCAL ECONOMY
}

\author{
SUMMARY
}

Social entrepreneurship, an element of "new social economy", operating under the Third Sector, is able to capture in an innovative way and to satisfy these social needs, which are unlikely to be fulfilled by the charity institutions and the state, due to their bureaucratic attitude, resisting change, lack of flexibility, innovation and creativity. The development of local entrepreneurship should be strongly supported by the local governments, universities and the media, because it can bring many socio-economic benefits to the individual, society and the world.

Keywords: social enterpreneurship, local development

JEL Classification: O17, P13

\section{WSTĘP}

Celem niniejszej pracy jest przedstawienie problemu przedsiębiorczości społecznej, korzyści oraz barier w powstawaniu przedsiębiorstw społecznych.

Przedsiębiorczość to działalność charakteryzująca się twórczym myśleniem oraz twórczym podejściem do zasobów ludzkich i rzeczowych, którymi rozporządza przedsiębiorstwo, w celu wykorzystania wszelkich szans, jakie przynosi rozwój nauki i techniki ${ }^{2}$. Przedsiębiorczość lokalna, to przedsiębiorczość mieszkańców danego terytorium. Jest ona stymulatorem wzrostu gospodarczego i rozwoju gospodarki całego kraju. „Przedsiębiorczość lokalną można określić jako takie działania podmiotów funkcjonujących na danym lokalnym terytorium, które prowadzą do powstawania nowych przedsiębiorstw na jego terenie, co powoduje rozwój gospodarczy na tym terytorium, a przez to podwyższenie stopy życiowej jego mieszkańców oraz takie działania władz lokalnych oraz środowisk około biznesowych, które stymulują powstawanie nowych przedsiębiorstw oraz rozwój infrastruktury technicznej i społecznej”"

${ }^{2}$ J. Penc, Encyklopedia zarzadzania. Podstawowe kategorie i terminy, Wyd. WSSM, Eódź 2008, s. 744.

${ }_{3}^{3}$ M. A. Saar, Jak samorządy lokalne mogq wspierać rozwoój przedsiębiorczości, Wyd. Fachowe CeDeWu, Warszawa 2011, s. 12. 
Elementem przedsiębiorczości lokalnej jest przedsiębiorczość w jednostkach non profit, tzw. „przedsiębiorczość obywatelska”, czyli „proces rozwoju nowych przedsięwzięć w postaci usług i instytucji funkcjonujących dla dobra i realizacji celów społecznych danej społeczności czy grupy osób, z których osoby biorące udział w tym procesie nie czerpią korzyści materialnych"4. W polskiej literaturze pojęcie przedsiębiorczości obywatelskiej używa się zamiennie $z$ pojęciem przedsiębiorczości społecznej. W dalszym ciągu pracy będzie używane pojęcie przedsiębiorczości społecznej.

Przedsiębiorstwo społeczne jest elementem „nowej” ekonomii społecznej. Ekonomia społeczna należy natomiast do szeroko pojętego Trzeciego Sekto$\mathrm{ra}^{5}$, w ramach którego funkcjonuje „tradycyjna” ekonomia społeczna w postaci fundacji i stowarzyszeń oraz „nowa” ekonomia społeczna, do której zalicza się spółdzielnie socjalne, zakłady aktywności zawodowej, centra integracji społecznej oraz przedsiębiorstwa społeczne.

\section{PRZEDSIĘBIORSTWO SPOŁECZNE - CHARAKTERYSTYKA}

Według bardzo ogólnej definicji polskich badaczy, „Przedsiębiorstwo społeczne może być zdefiniowane jako prywatna, autonomiczna organizacja, dostarczająca produktów lub usług na rzecz szerszej społeczności (community), której założycielem albo zarządzającym jest grupa obywateli i w której, zakres korzyści materialnych podlega ograniczeniom. Przedsiębiorstwo społeczne przywiązuje dużą wagę do swej autonomii i gotowość do przyjmowania ekonomicznego ryzyka związanego z prowadzoną w sposób ciągły działalnością społeczno-ekonomiczną"

Bardziej szczegółowa definicja twórcy przedsiębiorstw społecznych -czyli praktyka - Muhammada Yunusa ${ }^{7}$, określa przedsiębiorstwo społeczne jako firmę, która nie przynosi strat ani dywidendy, służy do rozwiązania jakiegoś

${ }^{4}$ Za: M. Laszuk, Z. Paciorkiewicz, Czynniki i bariery przedsiębiorczości w gospodarce regionalnej i lokalnej, [w:] Z. Strzelecki (red.), Gospodarka regionalna i lokalna w Polsce czynniki i bariery, Oficyna Wyd. SGH, Warszawa 2011, s. 149.

5 Trzeci Sektor (system), to ogół prywatnych organizacji działających społecznie i nie dla zysku, czyli organizacje pozarządowe (non profit). Są one niezależne od administracji publicznej, zwykle działają jako stowarzyszenia lub fundacje. (Pierwszy sektor to administracja publiczna, drugi sektor to gospodarka, trzeci sektor to organizacje pozarządowe).

${ }^{6}$ K. Wygnański, F. Frączak, Ekonomia spoteczna w Polsce - definicje, zastosowania, oczekiwania, wątpliwości, EKONOMIA SPOEECZNA TEKSTY 2006, s. 19, www.es.teksty.ekonomiaspołeczna.pl, (czerwiec 2012).

${ }_{7}$ Muhammad Yunus, profesor ekonomii, twórca Grameen Banku udzielającego w Bangladeszu kredytów bez zabezpieczenia osobom ubogim; otrzymał Pokojową Nagrodę Nobla w 2006 
problemu społecznego i jest własnością inwestorów, którzy reinwestują wszystkie zyski w rozwój i doskonalenie przedsiębiorstwa. Wyróżnia on dwa typy przedsiębiorstwa społecznego: I typu - jak wyżej, oraz II typu, czyli takie, którego właścicielami są ludzie ubodzy i którzy otrzymują dywidendę. Przykładem takiej firmy jest Grameen Bank, stworzony przez M. Yunusa ${ }^{8}$.

Przedsiębiorstwo spoteczne $(\mathrm{PS})=0$ strat +0 zysku = korzyść spoteczna,

Zdaniem Yunusa nikt nie może zarabiać na ubóstwie, ponieważ jest to niemoralne. Główną cechą PS jest to, że opiera się ono na altruistycznej stronie natury ludzkiej. Motywem działania ludzi, którzy tworzą PS, jest rozwiązanie jakiegoś problemu społecznego, możliwość wpływu na życie innych ludzi, wkład w społeczeństwo, satysfakcja i przyjemność płynąca $z$ takiego działania. Celem PS jest rozwiązanie problemu społecznego, za pomocą działalności gospodarczej, która może mieć formę produkcyjną lub usługową. Tym głównie różni się PS od organizacji „starej ekonomii”, takich jak np. fundacja, która jest organizacją charytatywną, utworzoną w celu wydatkowania funduszy uzyskanych od jednego lub więcej darczyńców, którzy starają się o to, aby ich dary przynosiły korzyści społeczne.

Źródła finansowania PS mogą być takie same jak w fundacjach czyli można je pozyskiwać od darczyńców, z grantów, od firm w ramach ich funduszy przeznaczonych na Społeczną Odpowiedzialność Biznesu lub z pożyczek. Różnica jest taka, że te fundusze muszą się zwrócić. Pożyczkodawcy mogą otrzymać zwrot pożyczonej kwoty ale bez zysku. Natomiast jeśli pożyczkodawcy nie chcą odzyskać swoich pieniędzy, to suma ta jest przeznaczona na rozwój danego przedsiębiorstwa, lub na stworzenie innego.

Zasady działalności przedsiębiorstw społecznych wg M. Yunusa, są następujące:

- celem przedsiębiorstwa społecznego jest przezwyciężenie ubóstwa, lub rozwiązanie jakiegoś problemu społecznego, a nie maksymalizacja zysku;

- spółka ma stan równowagi finansowej i ekonomicznej;

- inwestorzy (pożyczkodawcy) otrzymują tylko zwrot tej części kwoty, którą zainwestowali; nie ma dywidendy;

- po zwrocie pożyczek, osiągnięty zysk pozostaje w spółce i jest przeznaczony na rozwój;

— spółka jest świadoma znaczenia ochrony środowiska;

roku, jako wyraz poparcia dla tezy, że ubóstwo stanowi zagrożenie dla pokoju. Jego idea rozpowszechnia się na całym świecie, współpracują z nim uniwersytety w Europie i w USA.

${ }^{8}$ M. Yunus, Przedsiębiorstwo spoteczne kapitalizm dla ludzi, Wyd. ConCorda, Warszawa 2011. 
— pracownicy są wysokopłatni - otrzymują wynagrodzenie w wysokości obowiązującej na rynku pracy przy lepszych warunkach pracy; ponieważ

- pracują z radością

Tabela 1. Różnice między organizacją non profit a przedsiębiorstwem społecznym

\begin{tabular}{|c|c|c|c|}
\hline LP. & CZYNNIK & $\begin{array}{l}\text { "STARA" EKONOMIA } \\
\text { FUNDACJA, STOWARZYSZENIE } \\
\text { ORGANIZACJA FILANTROPIJNA }\end{array}$ & $\begin{array}{l}\text { "NOWA" EKONOMIA } \\
\text { PRZEDSIĘBIORSTWO SPOŁECZNE } \\
\text { SPÓŁDZIELNIA SOCJALNA }\end{array}$ \\
\hline 1 & Forma własności & Nie ma inwestorów i właścicieli & Ma inwestorów i właścicieli \\
\hline 2 & Źródła finansowania & $\begin{array}{l}\text { Zewnętrzne: dotacje, dary, granty = brak } \\
\text { samowystarczalności finansowej }\end{array}$ & $\begin{array}{c}\text { Granty, pożyczki, kredyty, własne źród- } \\
\text { ła finansowania }=\text { samowystarczalność fi- } \\
\text { nansowa }\end{array}$ \\
\hline 3 & Zatrudnienie & $\begin{array}{l}\text { Pracownicy nisko płatni/ wolontariusze, } \\
\text { bardziej idealiści niż przedsiębiorcy }\end{array}$ & $\begin{array}{c}\text { Wysoko wykwalifikowani pracownicy na } \\
\text { etacie z wynagrodzeniem obowiązującym } \\
\text { na rynku pracy }\end{array}$ \\
\hline 4 & Struktura & Brak struktury biznesowej & Posiada strukturę biznesową \\
\hline 5 & Zysk & Nie generuje zysku & Generuje zysk \\
\hline 6 & Ryzyko & Brak ryzyka & Jest ryzyko \\
\hline 7 & Nastawienie & Na darczyńców & Na klienta \\
\hline 8 & Wpływ społeczny & $\begin{array}{l}\text { Uzależnianie ludzi od pomocy zewnętrz- } \\
\text { nej, pozbawianie inicjatywy }\end{array}$ & $\begin{array}{l}\text { Wyzwalanie potencjału, aktywizacja, za- } \\
\text { chowanie autonomii i godności osobistej }\end{array}$ \\
\hline 9 & Zależność & Od darczyńców & Od siebie \\
\hline 10 & Korzyści społeczne & $\begin{array}{c}\text { Pomoc doraźna („rybka”), tworzy posta- } \\
\text { wy roszczeniowe, utrwala bezradność } \\
\text { i marazm }\end{array}$ & $\begin{array}{c}\text { Pomoc długotrwała, samowystarczalność, } \\
\text { („wędka”) likwiduje problem bezrobocia } \\
\text { i inne problemy wynikające z długotrwałe- } \\
\text { go bezrobocia, rozwija przedsiębiorczość, } \\
\text { daje przykład „dobrych praktyk" }\end{array}$ \\
\hline 11 & $\begin{array}{l}\text { Korzyści ekono- } \\
\text { miczne }\end{array}$ & Miejsca pracy, likwidacja ubóstwa & $\begin{array}{l}\text { Nowe miejsca pracy, wzrost PKB, likwida- } \\
\text { cja ubóstwa, wzrost przedsiębiorczości }\end{array}$ \\
\hline
\end{tabular}

Źródło: opracowanie własne.

Tworzenie przedsiębiorstw społecznych to wyzwanie dla idealistów przedsiębiorców, ludzi z misją/pasją/wizją ale i z umiejętnościami menedżerskimi. Takich ludzi ASHOKA ${ }^{10}$ nazywa innowatorami społecznymi. Wprowadzają oni zmiany - innowacje społeczne. ASHOKA poszukuje takich ludzi i wspomaga ich finansowo za pomocą stypendiów. Misją tej organizacji jest

9 Ibidem, s. 38-39.

${ }^{10}$ ASHOKA - międzynarodowa organizacja ,która wyszukuje, zrzesza i daje wsparcie finansowe dla osób wprowadzających innowacje społeczne, czyli rozwiązania problemów społecznych. Działalność ASHOKI finansują fundacje i osoby prywatne, chcąc zachować niezależność nie korzysta ona z żadnych środków publicznych. Organizacja ma zasięg globalny - około 70 krajów, w tym Polska, www.ashoka.pl. 
budowanie społeczeństwa obywatelskiego, w którym każdy ma możliwość i wsparcie dla wprowadzania zmian.

\section{KORZYŚCI Z PRZEDSIĘBIORCZOŚCI SPOŁECZNEJ}

Korzyści płynące z działalności przedsiębiorstw społecznych, są wielostronne: społeczne i ekonomiczne, mogą też dotyczyć różnej skali: jednostkowej, społecznej i globalnej.

Korzyści jednostkowe to możliwość stworzenia miejsca pracy dla jego twórcy i dla innych ludzi. Prowadzenie takiej firmy to rozwój swego potencjału i kreatywności, to zaspokojenie potrzeb wyższych, satysfakcja $\mathrm{z}$ wpływania na życie innych ludzi, oraz na społeczeństwo. To robienie czegoś ważnego. PS daje możliwość porzucenia pozycji klienta - bycia osobą uzależnioną od innych, niewykorzystującą swego potencjału, i stania się autonomiczną jednostką zdolną do samodzielnego dbania o swój los. To odzyskanie godności i wolności ekonomicznej.

Korzyści społeczne to przede wszystkim rozwiązanie jakiegoś problemu społecznego, stworzenie miejsc pracy, inkluzja społeczna ludzi wykluczonych, a tym samym odciążenie państwa $\mathrm{z}$ wydatków na opiekę społeczną; wzrost dobrobytu grup upośledzonych społecznie, rozwój lokalnej gospodarki. Dzięki temu zwiększa się solidarność społeczna i poczucie wspólnoty, zwiększa się zaangażowanie obywateli, wzrasta zakres współpracy z samorządem lokalnym. Wzrasta spójność społeczna - tworzą się zręby pod społeczeństwo obywatelskie. Przedsiębiorczość społeczna to szansa dla absolwentów szkół wyższych, którzy po ukończeniu studiów podejmują się pracy poniżej swoich możliwości, i tym samym nie ma zwrotu $\mathrm{z}$ inwestycji państwa $\mathrm{w}$ ich wykształcenie a oni nie wykorzystują swojego potencjału.

Korzyści globalne to rozwój i rozpowszechnianie idei przedsiębiorczości społecznej na cały świat, tak jak to robią Muhammad Yunus i twórca Ashoki Bill Drayton. Yunus rozpoczął swoją działalność od podarowania 27 dolarów ubogim mieszkankom wioski w Bangladeszu, uzależnionym od miejscowego lichwiarza, a teraz jego idee dotyczące mikrokredytów dla ubogich, oraz przedsiębiorstw społecznych, których właścicielami są ludzie ubodzy, rozpowszechniają się na całym świecie, również za pomocą uniwersytetów.

Organizacja Ashoka: Społeczni Innowatorzy, założona przez Draytona, w 1978 roku, do roku 2006 wsparła 1820 przedsiębiorstw społecznych (członków Ashoki) w 68 krajach Azji, Afryki, obydwu Ameryk i Europy, na sumę około $65 \mathrm{mln}$ dolarów. 
Zdaniem Davida Bornsteina przedsiębiorczość społeczna może zainicjować globalne zmiany społeczne. W USA, oprócz ludzi młodych angażujących się w przedsiębiorczość i znajdujących tym samym sposób na życie i karierę, również emeryci - ludzie w wieku sześćdziesięciu, siedemdziesięciu a nawet osiemdziesięciu lat - robią „drugą karierę” w przedsiębiorczości społecznej inwestując w ten sposób nadmiar wolnego czasu i nadając swemu życiu nowy, głębszy sens oraz uciekając $\mathrm{w}$ ten sposób od lęku przed samotnością, chorobą i śmiercią ${ }^{11}$.

We współczesnym społeczeństwie powstał nowy problem - problem czasu wolnego, wynikający $\mathrm{z}$ rozwoju technologii, bezrobocia technologicznego, skracania czasu pracy. Coraz więcej ludzi ma w nadmiarze czas, który mógłby być zainwestowany w działalność w ramach społecznej przedsiębiorczości, tak aby odnieść konkretną korzyść materialną, ulepszyć swoje otoczenie i nadać życiu sens oraz stać się potrzebnym. Niestety istnieje wiele barier w rozwoju przedsiębiorczości społecznej, do których należą:

- brak ogólnej wiedzy na temat przedsiębiorczości społecznej i korzyści jakie ona przynosi dla jednostek i społeczeństwa;

- brak wiedzy i umiejętności - ludzie nastawieni na działalność społeczną z reguły nie posiadają umiejętności biznesowych, nie są przedsiębiorcami;

— brak przedsiębiorców społecznych - innowatorów społecznych, czyli ludzi $\mathrm{z}$ wizją;

- brak wzorów działania, zestawu „dobrych praktyk”;

- bariery prawne i organizacyjne ${ }^{12}$;

- brak zaufania społecznego;

- mentalność polskiego społeczeństwa (powszechne przekonanie, że nic się nie da zrobić, że nie warto, niechęć do działania i do brania odpowiedzialności z siebie i swoje życie, w społeczeństwie wciąż dominują postawy roszczeniowe);

- nieumiejętność pozyskiwania środków finansowych;

— wysoki poziom ryzyka prowadzenia działalności gospodarczej.

\section{ZAKOŃCZENIE}

Badacz zjawiska przedsiębiorczości społecznej, David Bornstein, stwierdził, że: „Przedsiębiorczość społeczna jest wyjątkowo dobrze dopasowanym

11 D. Bornstein, op. cit., s. 15.

12 Bariery prawne uniemożliwiły w Polsce rozwój samopomocowej organizacji, jaką jest Bank Czasu. 
narzędziem do radzenia sobie $\mathrm{z}$ problemami, które do tej pory opierały się próbom rozwiązania, mimo poświęconej im pracy i pieniądzom"13.

W związku z powyższym stwierdzeniem, nasuwa się pytanie, $w$ jaki sposób i kto może wspomóc rozwój przedsiębiorczości społecznej. Wydaje się, że cztery instytucje mają możliwość bycia inicjatorem i katalizatorem rozwoju przedsiębiorczości społecznej: uniwersytety, media, samorządy lokalne i instytucje wspierające biznes.

Uniwersytety mogą odegrać ważną rolę w przyszłym rozwoju przedsiębiorstw społecznych, głównie poprzez edukację, ale mogą być również inicjatorami i katalizatorami $\mathrm{w}$ rozwoju tego procesu. Coraz większa liczba uniwersytetów na świecie zaczyna zajmować się tematem przedsiębiorczości społecznej ${ }^{14}$. W USA na Kalifornijskim Uniwersytecie Stanowym, powstał w roku 2010Instytut Przedsiębiorstwa Społecznego (California Institute of Social Business), który oprócz nauczania przedsiębiorczości społecznej, ma $\mathrm{w}$ planach również stworzenie funduszy inwestycyjnych do wspierania nowych przedsiębiorstw społecznych.

Najlepsze uczelnie na świecie ( Harvard, Stanford) mają w swojej ofercie fakultety z przedsiębiorczości społecznej, w USA i w Kanadzie ponad 200 uniwersytetów ufundowało stypendia, zorganizowało fakultety, konkursy, centra bądź cykle wykładów dotyczące przedsiębiorczości społecznej ${ }^{15}$. Pojawia się pytanie, czy nie można by było zaadaptować tych doświadczeń na polskim gruncie?

Pracodawcy potrzebują coraz mniej pracowników, wraz z rozwojem technologii kurczy się ilość miejsc pracy w gospodarce, wzrasta natomiast lawinowo ilość problemów społecznych. Państwo również zmniejsza swój udział w rozwiązywaniu problemów swoich obywateli, odchodzi w niepamięć wizja państwa opiekuńczego, rośnie za to wolność i niezależność obywateli, którzy sami muszą zatroszczyć się o siebie i swoje miejsce na ziemi. Wolność to odpowiedzialność za siebie, społeczeństwo i swoje środowisko.

Media mają szczególną moc kreacji (ale i destrukcji). W ramach Społecznej Odpowiedzialności Mediów ${ }^{16}$, mają one możliwość propagowania idei przedsiębiorczości społecznej. Poprzez filmy dokumentalne i reportaże można przybliżyć społeczeństwu tę ideę. Również poprzez wprowadzenie tej tematy-

13 D. Bornstein, op. cit., s. 12.

${ }^{14}$ M. Yunus, op. cit., s. 176-180.

15 D. Bornstein, op. cit., s. 10.

${ }^{16}$ Autorka postuluje wprowadzenie idei Społecznej Odpowiedzialności Mediów (analogicznie jak SOB - Społeczna Odpowiedzialność Biznesu). Media społecznie odpowiedzialne to media, które wprowadzają treści konstruktywne, a nie destrukcyjne i zadają sobie pytanie czy ich praca służy dobru społeczeństwa. 
ki do popularnych seriali telewizyjnych tak powszechnie oglądanych - można uczyć i inspirować społeczeństwo w tym, jakże pożądanym kierunku.

Samorządy lokalne mają wielkie możliwości wspierania przedsiębiorczości społecznej, ponieważ mogą tak kształtować swoją politykę podatkową, aby zachęcać i ułatwiać prowadzenie działalności gospodarczej.

Instytucje wspierające biznes mogą być finansowe oraz pozafinansowe. Instytucje finansowe, to banki, towarzystwa ubezpieczeniowe, fundusze poręczeniowe i fundusze pożyczkowe. Instytucja pozafinansowe, to instytuty szkoleniowo-badawcze, inkubatory przedsiębiorczości i parki naukowo-technologiczne. Wszystkie te instytucje mogą być zaangażowane w pomoc dla rozwijającej się przedsiębiorczości społecznej.

„Zakładanie i rozwijanie każdego małego przedsiębiorstwa społecznego przypomina pracę nad nową odmianą nasion. Jeśli się już taką odmianę wyhoduje, każdy może zasiać nasiona tam, gdzie jest to potrzebne. Ponieważ każda jednostka biznesowa jest samowystarczalna, finansowanie nie staje się ograniczeniem" ${ }^{17}$.

\section{BIBLIOGRAFIA}

Bornstein D., Jak zmieniać świat Przedsiębiorcy spoteczni - wizjonerzy naszych czasów, Wyd. AnWero, Gdańsk 2008.

Laszuk M., Paciorkiewicz Z., Czynniki i bariery przedsiębiorczości w gospodarce regionalnej i lokalnej, [w:] Z. Strzelecki (red.), Gospodarka regionalna i lokalna w Polsce czynniki i bariery, Oficyna Wyd. SGH, Warszawa 2011.

Penc J., Encyklopedia zarzadzania. Podstawowe kategorie i terminy, Wyd. WSSM, Łódź 2008.

Saar M. A, Jak samorzq̨dy lokalne mogq wspierać rozwój przedsiębiorczości, Wyd. Fachowe CeDeWu, Warszawa 2011.

www.ashoka.pl.

www.es.teksty.ekonomiaspołeczna.pl.

Wygnański K., Frączak., F., Ekonomia spoteczna w Polsce - definicje, zastosowania, oczekiwania, watpliwości, EKONOMIA SPOEECZNA TEKSTY 2006, wersja elektroniczna.

Yunus M., Przedsiębiorstwo spoteczne kapitalizm dla ludzi, ConCorda, Warszawa 2011.

${ }^{17}$ M. Yunus, op. cit., s. 33. 
